\title{
Результаты сортоиспытания сортов и гибридов редиса
}

\section{А.А. Миронов, А.А. Ушанов, К.А. Егоров, А.Э. Алексеев}

В условиях весеннего оборота в пленочных необогреваемых теплицах дана оценка урожайных качеств наиболее выращиваемых сортов и гибридов. Выделены сорта (Французский завтрак и Соренто) гибриды ( $F_{1}$ Вена, $F_{1}$ Донар и $\mathrm{F}_{1}$ Глориет), при одинаковой агротехнике и периоде вегетации, по сравнению с конкурентами, дающие наибольшую массу корнеплода.

Ключевые слова: редис, сортоиспытание. едис - весьма скороспелая и урожайная культура, которую выращивают повсеместно. Более высокая цена на ранневесеннюю продукцию, поиск энерго- и ресурсосберегающих технологий для повышения рентабельности приводит товаропроизводителей к выращиванию редиса в условиях гидропоники, либо в пленочных теплицах $[1,2]$. Выбор семян селекционного достижения для выращивания в России ограничен узким списком сортов и гибридов для промышленного производства. Несмотря на неоспоримые преимущества гибридов, по прежнему продаются в больших количествах семена сортов, и все эти селекционные достижения нуждаются в сортоиспытании - проверке заявленных характеристик в условиях хозяйства $[3,4]$.

Цель работы: оценка урожайных качеств районированных, наиболее возделываемых сортов и гибридов редиса в условиях пленочных необогреваемых теплиц в НЧЗ РФ.

Исследования провели в 201819 году на базе ООО «Селекционная станция имени Н.Н. Тимофеева» (подразделение ФГБОУ ВО РГАУ-МСХА имени К.А. Тимирязева, г. Москва). Теплица: пленка в один слой, отопление аварийное на зимний период, пло-

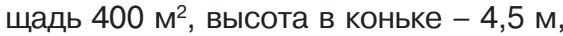
производитель - Richel. Уборка - одноразовая 11 мая (2018 год) и 13 мая (2019 год) (период вегетации - 41 сут), схема - 8×8 см, глубина 1-1,5 cм. Опыт был заложен в трехкратной повторности, по 240 растений в каждой, методом рендомизированных повторений [5]. В каждой повторности для анализа брали по 50 растений в середине делянки (кроме крайних рядов). Оценку достоверности различий проводили методом однофакторного дисперсионного анализа. Внутреннюю структуру оценивали по следующей шкале: 5 баллов - на срезе корнеплод белый, однородный по структуре, плотный, без пустот; 4 балла - единичные стекловидные вкрапления и/или единичные участки дрябления (ватная структура) и/или пустоты до 10\% объема; 3 балла - от 10 до 30\% стекловидности и/или от 10 до 49\% дрябления и/ или от 11 до 30\% пустот; 2 балла - от 50 до 90\% дряблый с пустотами и/или пустоты от 30 до 50\%; 1 балл - 100\% дряблый и/или пустоты более 50\%.

Редис сорта Французский завтрак выделяется наибольшей массой товарной части среди сортов, в первую очередь за счет удлиненной формы корнеплода, но статистически показатели его средней массы корнеплода незначительно отличаются от показателей сортов Соренто и Дуро краснодарское. В данном исследовании корнеплоды этого сорта имели дряблую структуру, что не позволяет рекомендовать его для хоть сколько-нибудь длительного хранения и производства в коммерческих целях.

Сорт Соренто выделился как лучший среди сортов по комплексу признаков для товарного производства: округлой формой, интенсивной красной окраской, высокой средней массой корнеплода и наиболее выровненным размером корнеплодов.

Среди гибридов первого поколения выделился $F_{1}$ Вена по массе корнеплода, существенно превзошедший все образцы $(4,3$ кг/M²). Небольшой недостаток гибрида - склонность к переходу от округлой к удлиненной форме корнеплода, что возможно исправить другой схемой выращивания.

Растения гибрида $\mathrm{F}_{1}$ Донар предназначенного для ранневесеннего посева, имели в два раза меньшую урожайность и нехарактерно вытягивались.

Самый популярный в России гибрид $\mathrm{F}_{1}$ Селеста не подходит для ранневесеннего срока получения товарной продукции. При недостатке освещенности этот гибрид показал наименьшую урожайность.

Ни у одного из образцов не было отмечено стеблевание. Наибольшей выравненностью корнеплодов среди сортов обладал Соренто, все гибриды также имели малый коэффициент вариации.

\begin{tabular}{|c|c|c|c|c|c|}
\hline \multirow[b]{2}{*}{ Сорт, гибрид } & \multicolumn{5}{|c|}{ Показатель корнеплода } \\
\hline & масcа, г & длина, мм & $\begin{array}{c}\text { диаметр, } \\
\text { мм }\end{array}$ & $\begin{array}{l}\text { индекс } \\
\text { формы }\end{array}$ & $\begin{array}{c}\text { внутренняя } \\
\text { структура, балл }\end{array}$ \\
\hline $\begin{array}{l}\text { Французский } \\
\text { завтрак }\end{array}$ & 19,0 & 58,8 & 22,4 & 2,6 & 3 \\
\hline Соренто (сора) & 17,0 & 32 & 30,8 & 1,0 & 4,4 \\
\hline $\begin{array}{l}\text { Дуро } \\
\text { краснодарское }\end{array}$ & 16,6 & 29,3 & 30,1 & 1,0 & 5 \\
\hline Рудольф & 12,0 & 24,1 & 23,4 & 1,0 & 5 \\
\hline$F_{1}$ Селеста & 12,2 & 29,7 & 28,1 & 1,0 & 4,4 \\
\hline $\mathrm{F}_{1}$ Донар & 19,2 & 39,2 & 29 & 1,4 & 4,5 \\
\hline $\mathrm{F}_{1}$ Mapc & 15,7 & 31,2 & 28,5 & 1,1 & 5 \\
\hline $\mathrm{F}_{1}$ Вена & 27,3 & 36 & 33,8 & 1,1 & 4,6 \\
\hline$F_{1}$ Глориет & 19,7 & 31,2 & 31 & 1,0 & 4,8 \\
\hline F, Черриэт & 17,7 & 29,5 & 31,3 & 1,0 & 5 \\
\hline $\mathrm{HCP}_{05}$ & 4,3 & 11,2 & 6,3 & - & 0,4 \\
\hline
\end{tabular}



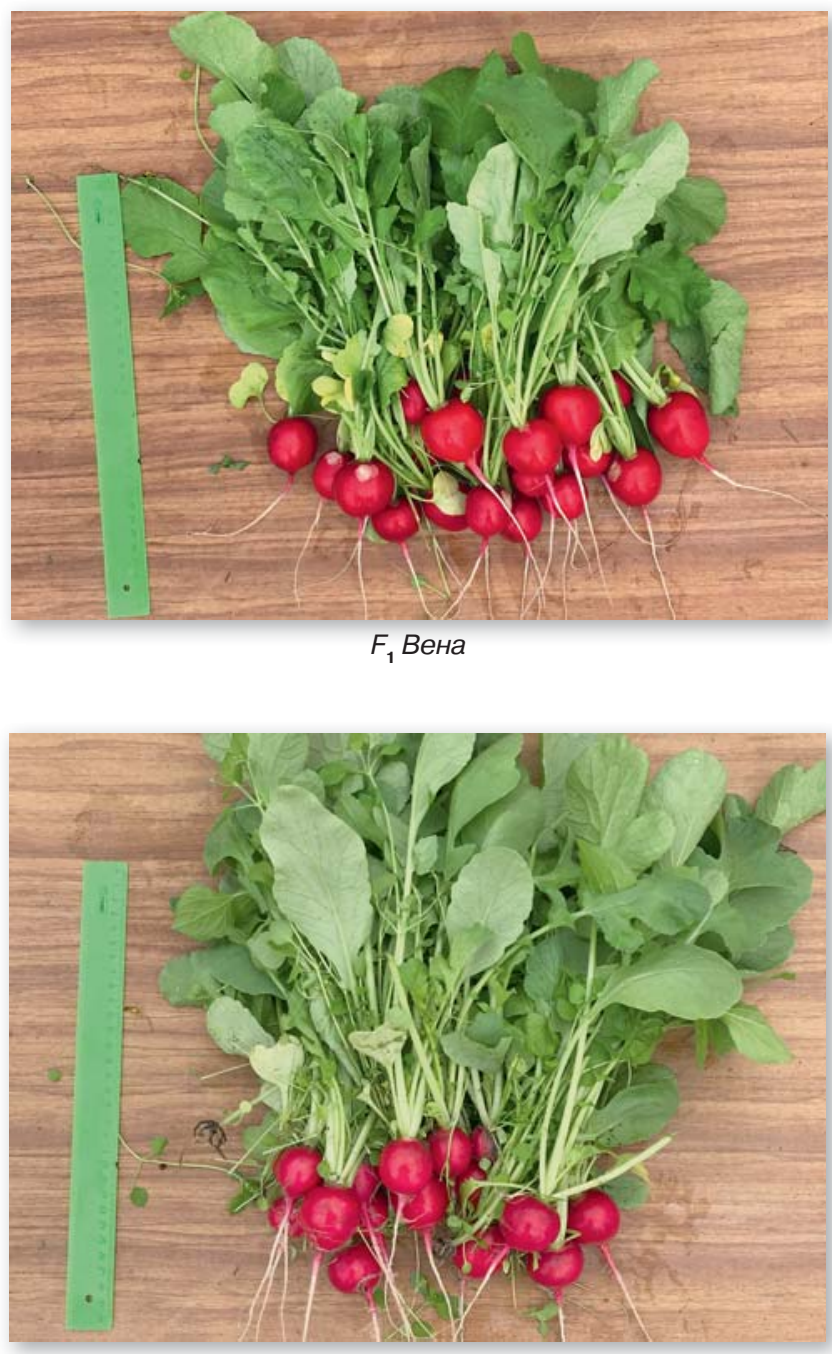

$F_{1}$ Глориэт

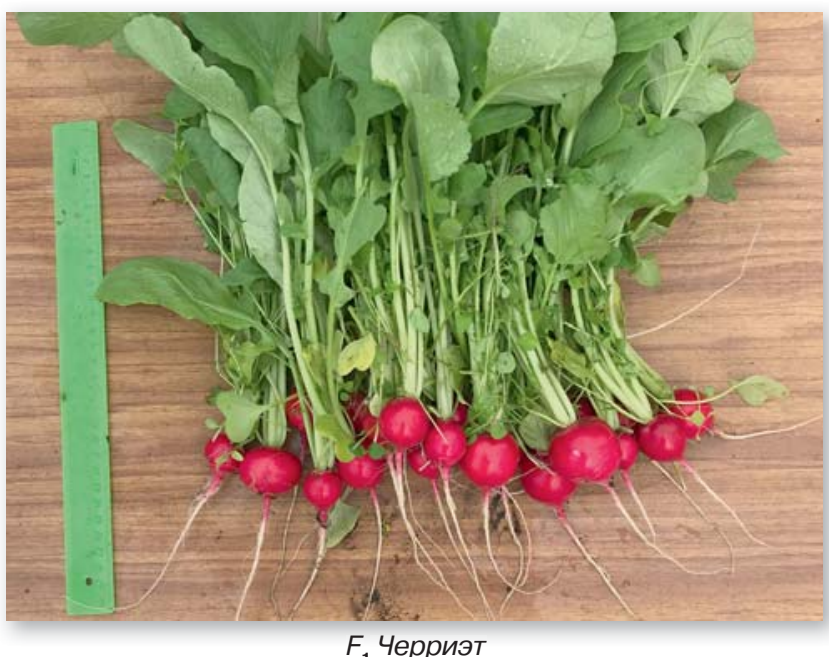

По результатам исследования гибрид Вена имел лучшие показатели и его целесообразнее выращи- вать в пленочных необогреваемых теплицах, при ранневесеннем посеве в условиях НЧЗ РФ. Среди сортов, наиболее подходящим к требованиям товаропроизводителей, выделился Соренто.

\section{Библиографический} СписОК

1.Колпаков Н.А. Весеннее выращивание редиса в зимних теплицах // Картофель и овощи. 2013. № 6. C. 21.

2.Янаева Д.А., Ховрин А.Н. Новые признаки в гетерозисной селекции редиса // Картофель и овощи. 2018. № 4. С. 39-40. 3.Куликов И.П. Результаты динамического сортоиспытания редиса в условиях Среднего Поволжья //Селекция и семеноводство сельскохозяйственных культур. 2005. С. 63-66.

4.Куликов И.П. Результаты сортоиспытания редиса в условиях Пензенской области // Актуальные проблемы земледелия на современном этапе развития сельского хозяйства. 2004. C. 197-198.

5.Доспехов Б.А. Методика полевого опыта. М.: Агропромиздат, 1985. $351 \mathrm{c}$.

\section{Об авторах Миронов Алексей Александрович,} канд. с. - х. наук, доцент кафедры ботаники, селекции и семеноводства садовых растений, ФГБОУ ВО РГАУ-МСХА именИ К.А. Тимирязева». Тел. +7 (499) 976-4171.

E-mail: alexeimrnv@ gmail.com

Ушанов Александр Анатольевич, канд. c. - х. наук, доцент кафедры ботаники, селекции и семеноводства садовых растений, ФГБОУ ВО РГАУ-МСХА им. К.А.

Тимирязева.

Тел. +7 (499) 976-4171.

E-mail: ushanov. aleksand@mail.ru

\section{Егоров Кирилл}

Андреевич, М.Н.С., ООО «Селекционная станция имени Н.Н. Тимофеева». Тел. +7 (499) 976-41-71.

E-mail: breedst@mail.ru

\section{Алексеев Алексей Эдуардович,} м.н.с., ООО «Селекционная станция имени Н.Н. Тимофеева». Тел. +7 (499) 976-41-71

E-mail: breedst@mail.ru

The results of testing of radish cultivars A.A. Mironov, $P h D$, associate professor, Department of Botany, Plant Breeding and Seed Technology, RSAU-MAA

Phone: +7 (499) 976-41-71

E-mail: alexeimrnv@gmail.com

A.A. Ushanov, PhD, associate professor, Department of Botany, Plant Breeding and Seed Technology, RSAU-MAA.

Phone: +7 (499) 976-41-71

E-mail: ushanov.aleksand@mail.ru K.A. Egorov, junior research fellow, Limited company «Breeding station after N.N.

Timofeev».

Phone: +7 (499) 976-41-71

E-mail: breedst@mail.ru

A.E. Alekseev, junior research fellow,

Limited company «Breeding station after N.N. Timofeev».

Phone: +7 (499) 976-41-71

E-mail: breedst@mail.ru.

Summary. In conditions in film greenhouses, the yield characteristics of the most cultivated varieties and hybrids were assessed. The varieties (French breakfast and Sorento) and hybrids ( $F_{1}$ Vienna, $F_{1}$ Donar and $F_{1}$ Gloriet) are distinguished, with the same agricultural technology and growing season, compared with competitors, giving maximum mass of root.

Keywords: radish, varietal testing. 